\title{
Blended learning approach to teaching ESP case study of TED talks
}

\author{
M.A. Rudneva, N.G. Valeeva \\ Peoples' Friendship University of Russia (RUDN University) \\ 6 Miklukho-Maklaya St., Moscow, 117198, Russian Federation
}

This work analyzes implementation of TED talks as a part of ESP blended learning training for fostering students' listening comprehension skills. We present a case study of 12 lower proficiency nonlinguistic students who were assigned listening to a designated TED talks each week and performing listening comprehension tasks that were later checked in the classroom. TED lectures were offered as a part of academic and specific English course for undergraduate students of the ecological faculty and were aimed at enhancing learner autonomy, enriching academic vocabulary, developing listening comprehension skills and promoting scholarly journal writing in a long-term perspective. The results were formally assessed by pre-test and post-test as well as by individual anonymous surveying of the students upon completion of the course. We looked into the results of the survey and overviewed pros and cons of implementation of TED talks into ESP curriculum.

Keywords: blended learning; listening comprehension; English for specific purposes

\section{Introduction}

The notion of blended leaning has existed in the field of language teaching for over a decade now [1]. Although a few interpretations of this term have been proposed, in this study we draw on C. Whittaker, who summarized it as "In ELT blended learning is the term most commonly used to refer to any combination of face-to-face teaching with computer technology (online and offline activities/materials)" [2]. There is an emerging body of blended language learning research with quite controversial results [3]. However, a few scholars agree that of all micro-skills listening has been significantly overlooked, with greater attention being paid to productive skills, i.e. speaking and writing, as well as reading, traditionally considered the key academic skill [4-6]. Although a few studies have argued the importance of listening comprehension in SLA pedagogy [7-9] it still remains a much neglected skill and has even been referred to as the "Cinderella" of communication strategies [6]. Even though the existing curriculum at Russian universities recognizes the value of listening comprehension, much deliberation is still needed to enhance curriculum design and foster language learners' listening abilities. At RUDN

(C) Rudneva M.A., Valeeva N.G., 2018

This work is licensed under a Creative Commons Attribution 4.0 International License 
University all students are encouraged to take Cambridge FCE or CAE examinations, depending on their level of language proficiency. Listening comprehension is an important part of examination and all students are taught listening strategies as a part of exam preparation in their general English classes. However, when it comes to ESP listening, the curriculum is limited to in-class activities. Taking into consideration limitations imposed by classroom time (on average 1 hour a week allocated to listening instruction with academic year lasting 34-36 weeks), and major focus on general English exam preparation, there is a significant need in off-site autonomous learning. The importance of extensive listening for proficiency development is not to be challenged; however, it is essential for the overall success that the teachers provide guidance and support for the extensive listening experiences, so that the students would benefit most from incorporation of authentic quasi-professional materials in their daily foreign language practices. This paper argues that it is essential to extend the existing on-site, process-oriented listening instruction by autonomous, learner-focused and self-regulated activities. We draw on the definition of self-regulated learning by P.R. Pintrich [10], stated as "an active constructive process whereby learners set goals for their learning and then attempt to monitor, regulate and control their cognition, motivation and behaviour, guided and constrained by their goals and the contextual features in the environment". The students who took part in the current study were responsible for the extent and degree of their personal involvement in overall development of listening skills.

\section{Methodology}

The case study presented in this paper was conducted at RUDN University (Russia) ecological faculty. 12 participants ( 5 male and 7 female) with an average age of 20 were selected from the same study group. They had been learning English for 8-10 years, depending on selected programme of secondary school education. Listening comprehension was practiced for the same time period; however, listening experience of specific ecological contexts was limited to 2 years of tertiary education. For the purpose of comparison all students were allocated into 3 categories with respect to their overall English proficiency, the placement was performed with respect to the entrance streaming test. The results are presented in Table 1.

Table 1

Categories of language proficiency

\begin{tabular}{|l|c|c|c|}
\hline & Intermediate & High-intermediate & Advanced \\
\hline Number of students & 4 & 6 & 2 \\
\hline
\end{tabular}

The off-site part of the blended learning curriculum was comprised with weekly assignments based on TED talks. We would like to argue the relevance of introducing TED talks into ESP curriculum. First of all, ted.com website currently offers $2900+$ talks on various subjects designed by top-notch professionals for general public. Among those over 200 talks are dedicated to environmental issues and can be used as specific language as well as content materials by novice environmentalists, such as our students. Secondly, all talks are featured with embedded interactive transcripts provided in various languages, English and Russian among those. Viewers can use the transcripts to enhance their understanding of the subject presented. Thirdly, the talks can be easily accessed, shared 
and downloaded, which makes them easy to be utilized as pedagogical contexts. Finally, these talks can be viewed any time and any place due to the development of Web 2.0 technologies, which facilitates individual, self-regulated character of autonomous learning. An essential part of course design was selecting the talks that would be relevant to the core curriculum of the students, only the topics already covered in L1 were offered in the course.

At the beginning of the pedagogical experiment the participants were offered a listening comprehension pretest based on the TED talks. The pretest included general comprehension questions as well as specific questions that targeted professional vocabulary. The pretest was on based a 50-mark system, the results are presented in Table 2.

Table 2

The results of listening pretest

\begin{tabular}{|l|c|c|c|}
\hline & Intermediate & High-intermediate & Advanced \\
\hline Out of 50, average & 25 & 34 & 39 \\
\hline
\end{tabular}

After the pretest the participants were receiving weekly listening comprehension assignments based on environmental TED talks that included pre-listening, whilelistening and post-listening tasks. The students were asked to work on the assignments individually, off-site. The on-site activities were reserved for content discussions in class, facilitated by the language teacher. All off-site assignments were checked in class, the problematic chunks were addressed and discussed. Apart from that, the students were instructed on listening strategies that would help them improve comprehension. In 14 weeks the students were asked to take a listening comprehension posttest, also based on the 50-mark system. A comparison of the participants' results for pretest and posttest was considered an indicator of the participants' improvement in listening comprehension. Apart from that the participants were asked to fill in the evaluation form, sharing their strategies of completing weekly assignments as well as their overall impression of their personal performance.

\section{Results}

Upon completion of the pedagogical experiment the students were asked to take a listening comprehension posttest, based on the 50-mark system. The results are presented in Table 3.

Table 3

The results of listening posttest

\begin{tabular}{|l|c|c|c|}
\hline & Intermediate & High-intermediate & Advanced \\
\hline Out of 50, average & 30 & 43 & 45 \\
\hline Improved by & $10 \%$ & $18 \%$ & $12 \%$ \\
\hline
\end{tabular}

Table 3 represents the improvement in the participants' listening comprehension performance. Intermediate students have enhanced their results by 5 marks (10\%), highintermediate - by 8 marks (18\%) and advanced ones by 6 marks (12\%).

The results illustrate more significant progress in the middle group, high-intermediate students, the advanced group placed second progress-wise, the intermediate group has demonstrated the least improvement of all. Although it is impossible to isolate the effect 
of the given experiment in overall improvement of language proficiency during the semester, it is still clear that higher achieving students paid more efforts and were more engaged in their listening practices, which resulted in better performance.

As for the qualitative assessment of the results of the experiment, the participants were requested to answer the anonymous open-clause questionnaire and share their reflections on the blended learning course as well and their individual approach to weekly assignments. According to the results of the survey, all groups of students were aware of the general goal of the assignments and were familiar with specific listening tasks prior to their blended learning experience. However, the personal approach to specific listening tasks as well as goal setting differed among the respective groups.

Intermediate students regarded listening as one of the most problematic skills, they acknowledged "lack of content knowledge", "lack of prior experience with lectures in L2", "high degree of anxiety when tackling the tasks". High-intermediate and advanced students considered listening tasks "challenging but engaging", among the shortcomings of the course they mentioned "arguable content", "unusual perspective", "new ways of presenting information, takes time to get used to". As can be seen from the results of the questionnaire, the group that lacks language proficiency is more concerned about linguistic challenges, whereas more advanced groups are concentrated on content structure of the course.

The groups also demonstrated very different approach to overall strategy of their listening practices, the results are presented in Table 4.

Table 4

Weekly listening practices

\begin{tabular}{|l|c|c|}
\hline & Repeated listening, times on average & Time of listening (minutes per week) \\
\hline Intermediate & 2,3 & 45 \\
\hline High-intermediate & 5,4 & 156 \\
\hline Advanced & 4,2 & 83 \\
\hline
\end{tabular}

As shown in Table 4, intermediate students spent only 45 minutes a week on improving their listening performance, advanced students invested 1.8 times more efforts, whereas the highest placing category progress-wise spent 3.5 times more in implementation of their listening development strategies. Apart from that, the number of repetitions differed for each category: intermediate students only listened to each lecture twice, whereas high-intermediate students repeated it 5.3 times, advanced students, however, limited themselves to about 4 repetitions. Such considerable difference of weekly implementation strategies comprises with the initial placement as well as reflected challenges for each group. Much poorer investment by an intermediate group can be put down to their initial high anxiety rate and limited expectations.

\section{Conclusions}

In this study we implemented a blended learning approach for developing specific listening skills in independent setting. TED talks were used to extend ESP curriculum and to overcome the gap between traditional academic skills, i.e. reading, writing and speaking, balancing out the listening component of the course. Familiar classroom-based, process-oriented approach to L2 listening instruction was replaced by autonomous, 
learner-oriented, self-regulated activities. The learners were given an opportunity to decide on the pace and implementation of their listening practices. The important result of this study is the overview of differential strategies of self-regulatory learning skills in L2 listening. It can be noted that lower-achieving students require more extensive instruction as well as considerable amount of positive reinforcement to overcome anxiety issues. This research is limited in its scope, of interest would be future research on cognitive and metacognitive aspects of listening development for different categories of students.

\section{References}

[1] Sharma P, Barrett B. Blended Learning. Oxford: Macmillan; 2007.

[2] Tomlinson B, Whittaker C. (eds.). Introduction. Blended Learning in English Language Teaching: Course Design and Implementation. 2013: 11-23.

[3] Aguilar M. Blended learning and the language teacher: a literature review. Colombia Applied Linguistics Journal. 2012;14(2): 163-180.

[4] Nation SP, Newton J. Teaching ESL/EFL listening and speaking. New York: Routledge; 2008.

[5] Nunan D. Designing and adapting materials to encourage learner autonomy. In: Benson P, Voller P (eds.) Autonomy and independence in language learning. London: Longman; 1997: 192-203.

[6] Vandergrift L. The Cinderella of communication strategies: Reception strategies in interactive listening. Modern Language Journal. 1997;81(4): 494-505.

[7] Feyten CM. The power of listening ability: an overlooked dimension in language acquisition. Modern Language Journal. 1991;75(2): 173-180.

[8] Wolvin AD. Listening and human communication in the 21st century. Malden, MA: WileyBlackwell; 2010.

[9] Wolvin AD, Coakley CG. Listening education in the 21st century. International Journal of Listening. 2000;14(1): 143-152.

[10] Pintrich PR. The role of goal orientation in self-regulated learning. In: Boekaerts M, Pintrich PR, Zeidner M (eds.). Handbook of self-regulation. San Diego, CA: Academic Press; 2000: 451-502.

Article history:

Received: 22.12.2018

Revised: 10.01 .2019

\section{For citation:}

Rudneva MA, Valeeva NG. Blended learning approach to teaching ESP case study of TED talks. RUDN Journal of Ecology and Life Safety. 2018;26(4): 454-460. DOI 10.22363/2313-2310-201826-4-454-460

\section{Bio Note:}

Maria A. Rudneva - Candidate of Philology, Associate Professor of the Department of Foreign Languages of the Environmental Faculty of the Peoples' Friendship University of Russia (RUDN University).Contact information: e-mail: rudneva_ma@rudn.university

Nailya G. Valeeva - Candidate of Pedagogical Sciences, Professor, Head of the Department of Foreign Languages of the Peoples' Friendship University of Russia (RUDN University) Ecological Faculty. Contact information: e-mail: valeeva_ng@rudn.university 


\title{
Смешанный подход к обучению иностранным языкам: внедрение TED talks
}

\author{
М.А. Руднева, Н.Г. Валеева \\ Российский университет дружбы народов \\ Российская Федерация, 117198, Москва, ул. Миклухо-Маклая, 6
}

В работе анализируется внедрение TED talks в рамках смешанного обучения ESP (English for Special Purposes) для развития у студентов навыков восприятия на слух. В исследовании приняли участие 12 студентов неязыковых специальностей с низким уровнем владения языком, которым было поручено слушать лекции TED talks каждую неделю и выполнять задания по аудированию с последующей проверкой в классе. Лекции TED talks были предложены как часть специального академического курса английского языка для студентов бакалавриата экологического факультета и направлены на повышение самостоятельности учащихся, расширение академического словарного запаса, развитие навыков восприятия на слух в долгосрочной перспективе. Результаты формально оценивались до и после теста, а также путем индивидуального анонимного опроса студентов по окончании курса. По результатам опроса выделены плюсы и минусы внедрения TED talks в учебную программу ESP.

Ключевые слова: смешанное обучение; аудирование; английский язык для специальных целей

\section{Список литературы}

[1] Шарма П., Барретт Б. Смешанное обучение. Оксфорд: Макмиллан, 2007.

[2] Введение // Смешанное обучение в преподавании английского языка: разработка и реализация курса / под ред. Б. Томлинсон, С. Уиттакер. 2013. С. 11-23.

[3] Агилар M. Смешанное обучение и преподаватель языка: обзор литературы // Колумбийский журнал прикладной лингвистики. 2012. № 14/2. С. 163-180.

[4] Национ С.П., Ньютон Дж. Обучение ESL/EFL аудированию и говорению. Нью-Йорк: Routledge, 2008.

[5] Нунан Д. Разработка и адаптация материалов для развития самостоятельности учащихся // Автономия и независимость в изучении языка / под ред. П. Бенсона, П. Воллера. Лондон: Longman, 1997. C. 192-203.

[6] Вандергриф Л. Золушка коммуникационных стратегий: стратегии приема в интерактивном аудировании // Modern Language Journal. 1997. Т. 81. № 4. С. 494-505.

[7] Фейтен С.М. Аудирование: пропущенное измерение в овладении языком // Modern Language Journal. 1991. T. 75. № 2. С. 173-180.

[8] Вольвин А.Д. Аудирование и общение с людьми в 21 веке. Малден, Массачусетс: WileyBlackwell, 2010.

[9] Wolvin A.D., Coakley C.G. Listening education in the 21st century // International Journal of Listening. 2000. Vol. 14. No. 1. Pp. 143-152.

[10] Пинтрич П.Р. Роль целенаправленной ориентации в саморегулируемом обучении // Справочник по саморегуляции / под ред. М. Букаертса, П.Р. Пинтрича, М. Зейднер. Сан-Диего, Калифорния: Academic Press, 2000. С. 451-502.

\section{История статьи:}

Дата поступления в редакцию: 22.12.2018

Дата принятия к печати: 10.01.2019 


\section{Для цитирования:}

Rudneva M.A., Valeeva N.G. Blended learning approach to teaching ESP case study of TED talks (Смешанный подход к обучению иностранным языкам: внедрение TED talks) // Вестник Российского университета дружбы народов. Серия: Экология и безопасность жизнедеятельности. 2018. Т. 26. № 4. С. 454-460. DOI 10.22363/2313-2310-2018-26-4-454-460

\section{Сведения об авторах:}

Руднева Мария Андреевна - кандидат филологических наук, доцент кафедры иностранных языков экологического факультета Российского университета дружбы народов. Контактная информация: e-mail: rudneva_ma@rudn.university

Валеева Наиля Гарифовна - кандидат педагогических наук, профессор, заведующая кафедрой иностранных языков экологического факультета Российского университета дружбы народов. Контактная информация: e-mail: valeeva_ng@rudn.university 